\title{
Ecological planning for the conservation and development of pineapple (Ananas comosus) in Tan Phuoc district, Tien Giang province
}

\author{
Mai T. Nguyen*, \& Thuy T. P. Doan \\ Department of Biology, Nong Lam University, Ho Chi Minh City, Vietnam
}

ARTICLE INFO
Research Paper
Received: March 11, 2019
Revised: May 19, 2019
Accepted: June 14, 2019
Keywords
Ecological planning
Land assessment
Mekong Delta
Pineapple
Sustainable development

*Corresponding author
Nguyen Thi Mai
Email: ngtpmai@hcmuaf.edu.vn

Cited as: Nguyen, M. T, \& Doan, T. T. P. (2019). Ecological planning for the conservation and development of pineapple (Ananas comosus) in Tan Phuoc district, Tien Giang province. The Journal of Agriculture and Development 18(3), 48-56.

\begin{abstract}
Land assessment is a specific requirement for the land use. Land assessment results provide the information on land types and natural conditions (land map units) so that we can evaluate the suitability of the land area for agricultural and non-agricultural use. In agriculture, appropriate crops for the land area are usually designed based on the land assessment data. Ecological planning is a process of assessment, evaluation, and decision in order to help authorities design the ideal, appropriate land area and land arrangement for agricultural and non-agricultural purposes. Tan Phuoc district in Tien Giang province is a low and alluvial agricultural area of Dong Thap Muoi. In this area, the income of local people depends majorly on agricultural activities. Pineapple (Ananas cosmosus) with its high economic value is widely cultivated in Tan Phuoc and has an important impact on the income of local people. Nevertheless, most of the land area currently used for pineapple production in Tan Phuoc was the land area previously used for cultivation of other crops. Due to this poor land resource planning, the yield of pineapple was low, and the land and environment were polluted. An adequate land assessment for Tan Phuoc is therefore highly needed so that an ecological planning for pineapple would be properly to improve the yield of pineapple, conserve the environment and support the sustainable development in Tan Phuoc.
\end{abstract}

\section{Introduction}

Tan Phuoc district in Tien Giang province is a low and alluvial agricultural area of Dong Thap Muoi. In this area, the income of the locals depends majorly on agricultural activities. Pineapple (Ananas cosmosus) with its high economic value was cultivated widely in Tan Phuoc and has an important impact on the locals' income. Nevertheless, the majority of the land area currently used for pineapple in Tan Phuoc was the land area of other crops. The pineapple farms in Tan Phuoc are formed by spontaneous farming, therefore the efficiency of using land resources is low. Furthermore, in this area the dike systems to protect pineapple farms are incomplete causing flooding causing unwanted affects on the farming productivity and environment. Until now, there has been no assessment of land adaptation and no adaptive zone was determined for pineapple cultivation, the crop that should only farmed in ideal farms with no flooding or flooding in less than 1 day with the submergence level is less than 30 $\mathrm{cm}$. These areas should not be affected by salinity or alluvium; the depth of alluvium layer is above $100 \mathrm{~cm}, \mathrm{pH} \leq 4.0$; annual rainfall is $1,000 \mathrm{~mm}$ to 


\section{1,500 mm (Nguyen, 2014).}

An adequate land assessment for Tan Phuoc is therefore highly needed so that a proper ecological planning for pineapple could be designed to improve the yield of pineapple, preserve the environment and support sustainable development in Tan Phuoc.

Ecological planning is a process of assessment, evaluation, and decision in order to help authorities design the ideal, appropriate land area and land arrangement for agricultural and nonagricultural purposes (Huizing, 1992). In order to use land resource efficiently, a proper assessment of land adaptation is highly needed to determine the adaptive area for the optimal growth of crops. A landscape ecological approach to protect the ecosystems and biological resources is an effective approach to ecological planning for sustainable development (Almo, 1998). This approach based on the integration planning between the need for economic development and the sustainable development of the land ecosystem in order to efficient exploit the potential and advantages of land units (FAO, 1976).

We conducted the research to define the adaptive areas and identify potential areas for pineapple cultivation. Our results therefore could be used as a fundamental data for the planning, conservation and development of pineapple to preserve the environment and support sustainable development in Tan Phuoc, Tien Giang.

\section{Materials and Methods}

\subsection{Materials}

Our study was conducted in Tan Phuoc, Tien Giang, an area of Dong Thap Muoi, Mekong Delta (Figure 1). This is an agricultural area with low, alum and organic soil formed from the sediments of coastal marshy, hence suitable for the growth of pineapple. Pineapple (Ananas comosus) belongs to Bromeliaceae family with the development depend on the depth of the alluvial soil layer $(\mathrm{cm})$, the depth of the alluvial forming layer $(\mathrm{cm})$, the submerged depth $(\mathrm{cm})$ and duration of submergence (day). In Tan Phuoc, pineapple has been farmed since 1983, in Tan Lap 1 and Tan Lap 2 wards. These two areas are notable for the brand "Tan Lap pineapple" with high fruit quality and productivity. The pineapple farms are expanding and there are 16,375.51 ha (DONRE,
2018).

\subsection{Methods}

\subsubsection{Data collection and field surveys}

The data include: land map, current land use map, administrative map scale 1: 100,000 was collected and provided by the DONRE, 2018.

Field surveys were conducted based on the data of land units, characteristics and growth conditions of pineapple; factors affecting the pineapple cultivation such as alluvium soil, flooding level etc. (DONRE, 2018).

\subsubsection{GIS and mapping}

Using GIS - Mapinfo software to create raster maps in Idrisi through data analysis combined with field survey results.

The map of land units, adaptation maps and ecological planning maps by overlapping the component maps (alluvial formation layer, the depth of alluvial layer, submerged depth and duration of submergence) was established based on soil characteristics and ecological factors for pineapple (Carol, 1998).

\subsubsection{Data analysis}

Data was analyzed using Excel và SPSS. All data was analyzed in both natural and economic factors to provide the conclusions and plans that support the developmental potential of the studied area.

\subsubsection{Assessment method for the natural, economic and ecological planning for pineapple}

The assessment of natural land adaptation according to FAO (1976) using MapInfo 11.0 software included the following steps: (1) Screening and description of land use; (2) Conversion of land characteristics of each land map unit into land quality; (3) Identification of land use requirements for land use patterns and ecological constraints affecting pineapple productivity. (4) Establishment of ecological adaptation chart for pineapple (S1(Highly Suitable), S2 (Moderately Suitable), S3 (Marginally Suitable), N (Not Suitable)). (5) Comparison, adaptation subdivision for pineapple and ecological land. 
ADMINISTRATIVE MAP

TAN PHUOC DISTRICT - TIEN GIANG PROVINCE

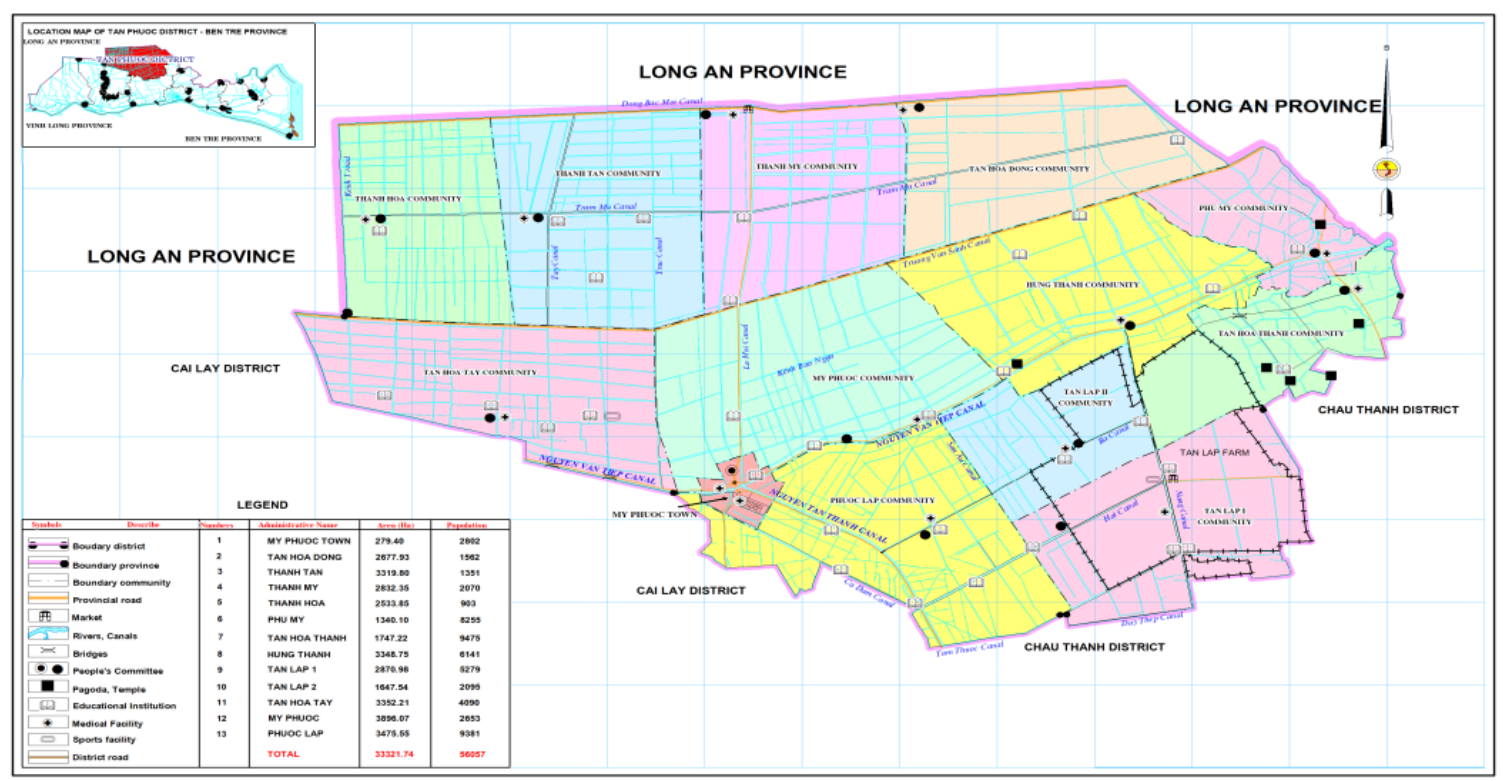

Scale 1: 100000

Figure 1. Administrative map of Tan Phuoc, Tien Giang province, Vietnam.

Estimation the adaptation of economic land based on the classification results of natural land adaptations S1, S2, S3 (according to FAO (1976)) and the productivity of the adaptive levels (that was calculated as the average of the optimal productivity based on the results of the field surveys) as follows:

- Productivity of S1: 90\% (maximum yield of crops in the studied area).

- Productivity S2: 60\% (compared to S1 yield).

- Productivity S3: 30\% (compared to S1 yield).

Estimation of economic adaptation (profitability and efficiency of capital using B/C (Benefit/Cost)) and classification of economic factors using the optimal percentage conversion method by FAO (1976), including:

- Highly adaptation S1: $\geq 80 \%$.

- Adaptation level S2: $\geq 40 \%$ to $<80 \%$.

- Adaptation level S3: $\geq 20 \%$ to $<40 \%$.

- Inappropriate N: $<20 \%$.

Ecological planning of the specialized area for pineapple: overlapping the ecological map and economical map, exploiting efficiently the natural ecological conditions, developing pineapple at an appropriate level (S1, S2) and less adaptable land (S3), based on the socio-economic development orientation; land use status and land resource characteristics such as soil type; water resources, irrigation system, submerge control, ecological planning for pineapple production area in Tan Phuoc district.

\section{Results and Discussion}

The overlapping layers of map information of natural ecological factors including soil map, submerged depth, duration of submergence, the depth of alluvial forming layer, the depth of alluvial layer were used to create the land unit map. Areas with the same land features were idenitifed as zone. A zone is an area with mogeneous natural features called land units. Our results showed that there were 26 land units in the studied area (Figure 2).

\subsection{Identification of land quality adaptation}

Based on the growth characteristics of pineapples, the natural conditions and land quality requirements and the detailed assessment criteria 


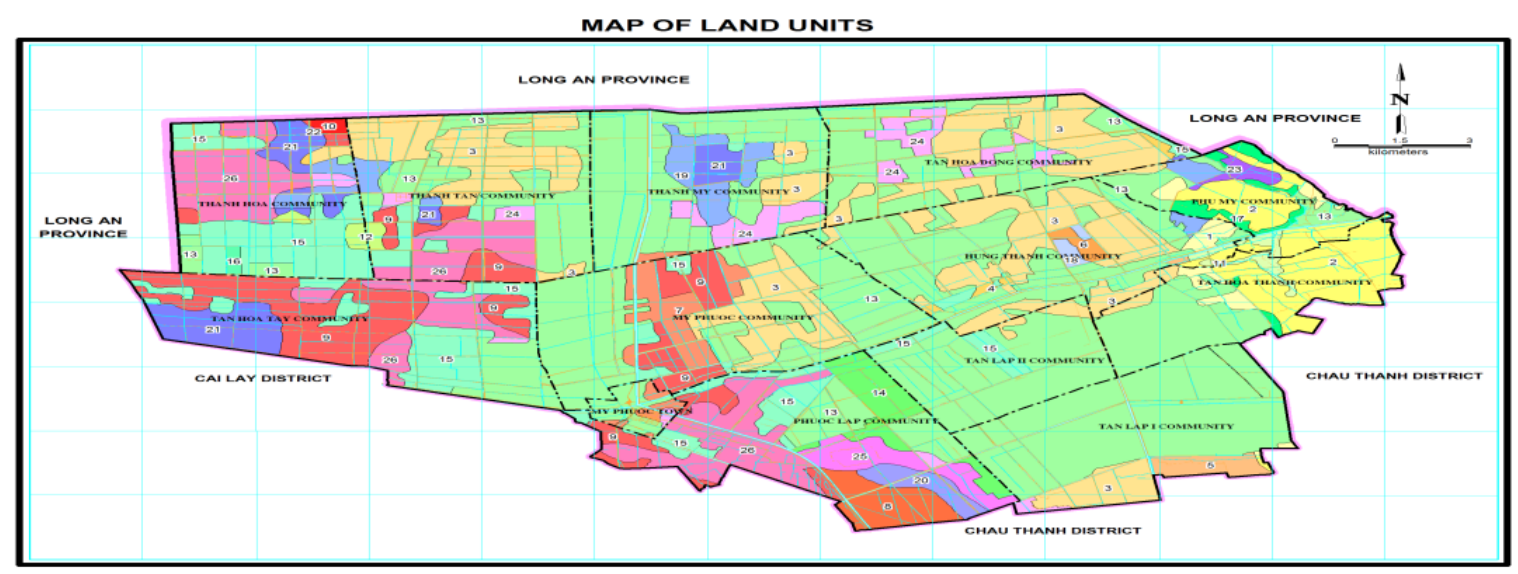

\begin{tabular}{|c|c|c|c|c|c|c|c|c|c|c|c|}
\hline \multicolumn{12}{|c|}{ LEGEND } \\
\hline LMU & $\begin{array}{l}\text { Aetual Acid } \\
\text { Sulfurie }\end{array}$ & $\begin{array}{l}\text { Potential Aoid } \\
\text { sulfidic }\end{array}$ & $\begin{array}{l}\text { Depth } \\
\text { of Inundat }\end{array}$ & $\begin{array}{l}\text { Duration } \\
\text { ion Flooding }\end{array}$ & Area (ha) & LMU & $\begin{array}{l}\text { Actual Acia } \\
\text { Sulfuric }\end{array}$ & $\begin{array}{c}\text { Potential Acid } \\
\text { Sulfidice }\end{array}$ & $\begin{array}{l}\text { Depth } \\
\text { of Inundat: }\end{array}$ & $\begin{array}{l}\text { Duration } \\
\text { on Flooding }\end{array}$ & Area (ha) \\
\hline 1 & & & & & 274,82 & 14 & $100-150 \mathrm{~cm}$ & $=150 \mathrm{~cm}$ & $=100 \mathrm{~cm}$ & 60 day & 463,72 \\
\hline 2 & & & $60-100 \mathrm{~cm}$ & 90 day & $1.475,35$ & 15 & $100-150 \mathrm{~cm}$ & $>150 \mathrm{~cm}$ & $-100 \mathrm{~cm}$ & 90 day & 2.610 .74 \\
\hline 3 & & $100-150 \mathrm{~cm}$ & & & 4.761 .06 & 16 & $100-150 \mathrm{~cm}$ & $=150 \mathrm{~cm}$ & $=100 \mathrm{~cm}$ & a roar & 36,38 \\
\hline 4 & & $100-150 \mathrm{~cm}$ & $>100 \mathrm{~cm}$ & so day & 69,22 & 17 & $100-150 \mathrm{~cm}$ & $>150 \mathrm{~cm}$ & $60-100 \mathrm{~cm}$ & so day & 211.53 \\
\hline 5 & & $100-150 \mathrm{~cm}$ & $80-100 \mathrm{~cm}$ & 90 day & 202,87 & 18 & $100-150 \mathrm{~cm}$ & $>150 \mathrm{~cm}$ & $<30 \mathrm{~cm}$ & 1-5 day & 64,94 \\
\hline 6 & 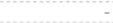 & $100-150 \mathrm{~cm}$ & $<30 \mathrm{~cm}$ & $1-5$ day & 74,24 & 19 & $50-100 \mathrm{~cm}$ & $100-150 \mathrm{~cm}$ & & & 662,61 \\
\hline 7 & $=$ & $50-100 \mathrm{~cm}$ & & & 548,33 & 20 & $50-100 \mathrm{~cm}$ & $100-150 \mathrm{~cm}$ & $-100 \mathrm{~cm}$ & 60 day & 208,98 \\
\hline 8 & & $50.100 \mathrm{~cm}$ & $=100 \mathrm{~cm}$ & 60 day & 411,16 & 21 & $50.100 \mathrm{~cm}$ & $100-150 \mathrm{~cm}$ & $>100 \mathrm{~cm}$ & so day & 871,37 \\
\hline 9 & 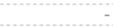 & $50-100 \mathrm{~cm}$ & $>100 \mathrm{~cm}$ & so day & 2.201 .06 & 22 & $50-100 \mathrm{~cm}$ & $100-150 \mathrm{~cm}$ & $=100 \mathrm{~cm}$ & a year & 5.41 \\
\hline 10 & & $80-100 \mathrm{~cm}$ & $>100 \mathrm{~cm}$ & a yoar & 46,02 & 23 & $50-100 \mathrm{~cm}$ & $100-150 \mathrm{~cm}$ & $60-100 \mathrm{~cm}$ & so day & 95,62 \\
\hline 11 & & $50-100 \mathrm{~cm}$ & $60-100 \mathrm{~cm}$ & so day & 145,47 & 24 & $<50 \mathrm{~cm}$ & $50-100 \mathrm{~cm}$ & & & 805,46 \\
\hline 12 & & $<50 \mathrm{~cm}$ & $>100 \mathrm{~cm}$ & 90 day & 116.09 & 25 & $<50 \mathrm{~cm}$ & $50-100 \mathrm{~cm}$ & $=100 \mathrm{~cm}$ & eo day & 376,84 \\
\hline 13 & $100-150 \mathrm{~cm}$ & $=150 \mathrm{~cm}$ & & & $14.036,97$ & 26 & $=50 \mathrm{~cm}$ & $50-100 \mathrm{~cm}$ & $=100 \mathrm{~cm}$ & so day & $2.556,48$ \\
\hline
\end{tabular}

Figure 2. Land unit map of Tan Phuoc, Tien Giang province, Vietnam.

that affect the land use types were described in Table 1 .

The identified adaptation levels for the types of pineapple land use are presented in Table 2 using the data of the land use requirement, the factors affecting the growth of pineapple in combination with the results of the land adaptation and land characterization.

\subsection{Identify the adaptation of land based on the natural ecological conditions}

The identification of land adaptation was conducted using FAO guidelines (1976). Using Table 2 , the evaluation of land quality of land map units for pineapple land showed that the land units number $1,3,13$ were the land units with highest adaptation; followed by the number 7 and 19 were inadequate adaptation; $6,18,24$ were less adaptable and finally the land units $2,4,5,8$ $12,14-17,20-23,25$ and 26 were unsuitable for pineapple cultivation (Table 3 ).

The adaptation of land for pineapple based on the natural ecological conditions:

From the adaptation result of the land use type for each land unit, adaptation zones were identi- fied using following steps: (1) determination of the acceptable levels of land use map units, (2) combinations of land units with similar level of adaptation (Tables 4 and 3).

In that, Zone I: Land units 1, 3, 13 (largest area with $19,072.85$ ha) were the land units with highest adaptation. This land units belong to Tan Lap 1, Tan Lap 2, Hung Thanh, My Phuoc, Tan Hoa Đong, Thanh Tan, Thanh My wards.

Zone II: Being 1,210.94 ha included the land units 7 and 19, were medium adaptive with the presence of alluvial layer and the alluvial forming layer in My Phuoc, Thanh My, Thanh Hoa and Thanh Tan wards. Zone II was also the third largest zone after zone I and III.

Zone III: Being 944,64 ha included the land units $6,18,24$, less adaptive with the presence of the alluvial forming layer and the duration of submergence in part of Tan Hoa Đong, Hung Thanh, Thanh My, Thanh Tan and Thanh Hoa wards. This zone was also the smallest zone.

Zone IV: Being 12,093.31 ha, the second largest zone, included the land units $2,4,5,8-17,20-23$, 25,26 , were unsuitable for pineapple due to the annual floods and partially used for aquaculture. This zone belongs to Tan Hoa Tay, Thanh Hoa, 
Table 1. The land use type, land quality requirement and assessment criteria to Pineaple cultivation

\begin{tabular}{lll}
\hline The land use type & Land quality & Assesment criteria \\
\hline & Alluvial risk & $\begin{array}{l}\text { The depth of the alluvial layer } \\
\text { The depth of the alluvial forming layer } \\
\text { Pineapple cultivation }\end{array}$ \\
& Submerged risk & $\begin{array}{l}\text { The submerged depth } \\
\text { Durarion of submergence }\end{array}$ \\
\hline
\end{tabular}

Table 2. The adaptation levels for pineapple

\begin{tabular}{|c|c|c|c|c|c|}
\hline \multirow{2}{*}{ Land type requirement } & \multirow{2}{*}{ Affecting factors } & \multicolumn{4}{|c|}{ Adaptation level } \\
\hline & & S1 & $\mathrm{S} 2$ & S3 & $\mathrm{N}$ \\
\hline \multirow{2}{*}{ Alluvial risk } & $\begin{array}{l}\text { The depth of the allu- } \\
\text { vial layer }(\mathrm{cm})\end{array}$ & $\begin{array}{l}\text { No alluvium } \\
\text { or }>100\end{array}$ & $50-100$ & $<50$ & - \\
\hline & $\begin{array}{l}\text { The depth of the allu- } \\
\text { vial forming layer }(\mathrm{cm})\end{array}$ & $\begin{array}{l}\text { No alluvium } \\
\text { or }>100\end{array}$ & $50-100$ & $<50$ & - \\
\hline \multirow{2}{*}{ Submerged risk } & $\begin{array}{l}\text { Duration of submer- } \\
\text { gence (day) }\end{array}$ & $\begin{array}{c}\text { No } \\
\text { submergence }\end{array}$ & $<1$ & $<5$ & $>5$ \\
\hline & $\begin{array}{l}\text { The depth of submer- } \\
\text { gence }(\mathrm{cm})\end{array}$ & $\begin{array}{c}\text { No } \\
\text { submergence }\end{array}$ & $0-30$ & $30-60$ & $>60$ \\
\hline
\end{tabular}

Table 3. The adaptation of land for pineapple based on the natural ecological conditions

\begin{tabular}{lccccc}
\hline Land unit & $\begin{array}{c}\text { The depth of } \\
\text { the alluvial } \\
\text { layer }(\mathrm{cm})\end{array}$ & $\begin{array}{c}\text { The depth of } \\
\text { the alluvial } \\
\text { forming } \\
\text { layer }(\mathrm{cm})\end{array}$ & $\begin{array}{c}\text { The depth of } \\
\text { submergence } \\
(\mathrm{cm})\end{array}$ & $\begin{array}{c}\text { Duration of } \\
\text { submergence } \\
\text { (day) }\end{array}$ & $\begin{array}{c}\text { Adaptation } \\
\text { level }\end{array}$ \\
\hline $1,3,13$ & $\mathrm{~S} 1$ & $\mathrm{~S} 1$ & $\mathrm{~S} 1$ & $\mathrm{~S} 1$ & $\mathrm{~S} 1$ \\
$2,4,5,14-$ & $\mathrm{S} 1$ & $\mathrm{~S} 1$ & $\mathrm{~N}$ & $\mathrm{~N}$ & $\mathrm{~N}$ \\
17 & $\mathrm{~S} 1$ & $\mathrm{~S} 1$ & $\mathrm{~S} 2$ & $\mathrm{~S} 3$ & $\mathrm{~S} 3$ \\
6,18 & $\mathrm{~S} 1$ & $\mathrm{~S} 2$ & $\mathrm{~S} 1$ & $\mathrm{~S} 1$ & $\mathrm{~S} 2$ \\
7 & $\mathrm{~S} 1$ & $\mathrm{~S} 2$ & $\mathrm{~N}$ & $\mathrm{~N}$ & $\mathrm{~N}$ \\
$8-11$ & $\mathrm{~S} 1$ & $\mathrm{~S} 3$ & $\mathrm{~N}$ & $\mathrm{~N}$ & $\mathrm{~N}$ \\
12 & $\mathrm{~S} 2$ & $\mathrm{~S} 1$ & $\mathrm{~S} 1$ & $\mathrm{~S} 1$ & $\mathrm{~S} 2$ \\
19 & $\mathrm{~S} 2$ & $\mathrm{~S} 1$ & $\mathrm{~N}$ & $\mathrm{~N}$ & $\mathrm{~N}$ \\
$20-23$ & $\mathrm{~S} 3$ & $\mathrm{~S} 2$ & $\mathrm{~S} 1$ & $\mathrm{~S} 1$ & $\mathrm{~S} 3$ \\
24 & $\mathrm{~S} 3$ & $\mathrm{~S} 2$ & $\mathrm{~N}$ & $\mathrm{~N}$ & $\mathrm{~N}$ \\
25,26 & & & & & \\
\hline
\end{tabular}

Thanh Tan, Phuoc Lap, Phu My, Tan Hoa Thanh and My Phuoc wards.

\subsection{Identify the adaptation of land based on the economical conditions}

The assessment of land suitability in terms of economics was evaluated in accordance with the objective of increasing profitability for the adaptive areas. Profit $=$ Total revenue - Cost; Effective use of capital B/C = Profit/Total cost; Total revenue $=$ Productivity ${ }^{*}$ Unit price. The results of field surveys for economic criteria in three regions S1, S2, S3 are summarized in Table 4.

From the results of the land based on the natural ecological conditions (Table 4), the levels of S1, S2, S3 of each land use type for land units and productivity levels are calculated as average optimum productivity according to FAO (1976).

The data from the comparation of the actual conditions in the studied area using the yield at the adaptive levels (after the conversion from the classification of natural ecological adaptation to 
Table 4. The adaptation of land for pineapple based on the natural ecological conditions

\begin{tabular}{llcc}
\hline Zone & Land unit & Adaptation levels & Area (ha) \\
\hline I & $1,3,13$ & S1 & $19.072,85$ \\
II & 7,19 & S2 & $1.210,94$ \\
III & $6,18,24$ & S3 & 944.64 \\
IV & $2,4,5,8-17,20-23,25,26$ & $\mathrm{~N}$ & $12.093,31$ \\
\hline Unit: & & &
\end{tabular}

the economic adaptation) was used to establish two economic criteria: profit and $\mathrm{B} / \mathrm{C}$, the results were shown in Table 5.

The analysis data on the profit and B/C therefore divided the studied area into 4 economical adaptation levels.

S1: Highly adaptive; S2: medium adaptive; S3: Low adaptive; N: unsuitable. The profitability and capital efficiency were established based on the economic values, at the natural level S1 of the land use type to determine levels of economic adaptability.

The economical adaptation levels by the FAO based on the optimal yield \% method according to FAO (1976) for land use were shown in Table 6.

\subsection{Identify the economical adaptation of land}

The results of economic aggregation (Table 5) and economic decentralization (Table 6) were compared and used to determine the economic suitability of land use patterns for each land unit and zone for pineapple. The results are shown in Table 7 and Table 8 .

Accordingly, the economical adaptation levels of land for pineapple were divided into 3 Zones.

Zone I with land units 1, 3, 13. This zone was $19.072,85$ ha and in S1 levels for profit and B/C.

Zone II with land units 7,19 . This zone was 1.210,94 ha and in S2 levels for profit and B/C.

Zone III with land units 6,18 and 24. This zone was 944,64 ha and in S3 levels for profit and B/C.

\subsection{Identify the adaptation of land for pineap- ple based on economy and ecology}

The adaptation of land for pineapple based on economy and ecology was established using the results on the adaptation analysis of economy and ecology. The results were shown in Table 9 and

www.jad.hcmuaf.edu.vn the distribution of zones was presented in Figure 3 .

- Using the results in table 9, the adaptation of land for pineapple based on the ecological and economical factors were defined in 4 zones (Figure 3):

Zone I: Land units 1, 3, 13 (were in S1 level on the ecology, profit and B/C). This zone was $19,072.85$ ha $(57,25 \%$ of the studied area $)$ including Tan Lap 1, Tan Lap 2, Hung Thanh, Tan Hoa Dong, My Phuoc, Thanh My, Thanh Tan wards. Zone I was highly adaptive for pineapple.

Zone II: Land units 7 and 19 (were in S2 level on the ecology, profit and $\mathrm{B} / \mathrm{C}$ ). This zone was $1,210.94$ ha $(3,63 \%$ of the studied area) distributed in Thanh My, Thanh Tan, Thanh Hoa, My Phuoc, Phu My, Hung Thanh and My Phuoc wards. Zone II was medium adaptive for pineapple.

Zone III: Land units 6, 18 and 24 (were in S3 level on the ecology, profit and B/C). This zone was 944,64 ha $(2,83 \%$ of the studied area) located in Thanh My, Thanh Tan, Thanh Hoa, Hung Thanh and Tan Lap 1, Phuoc Lap and Tan Hoa Tay wards. Zone III was less adaptive for pineapple.

Zone IV: 12.093,31 ha and accounted for $36,29 \%$ the studied area. This zone included land units $2,4,5,8,9,10,11,12,14,15,16,17,20,21$, $22,23,25,26$ with are not suitable for pineapple cultivation. Zone 4 distributed mostly in Thanh Tan, Thanh Hoa, Tan Hoa Tay, Tan Hoa Thanh, Phu My wards and partially in My Phuoc, Thanh My, Tan Lap 1 and Tan Lap 2.

- Ecological planning for pineapple cultivation area must:

Align with the agricultural development orientation of the local community.

Align with the land conditions and socioeconomical conditions.

Give the priority to the land use types that are medium to high level of adaptation; high yield 
Table 5. The adaptation of land for pineapple based on the natural ecological conditions

\begin{tabular}{lccc}
\hline \multirow{2}{*}{ Land unit } & \multicolumn{3}{c}{ Pineapple cultivation } \\
\cline { 2 - 4 } & Ecological adaptation level & Profit & $\mathrm{B} / \mathrm{C}$ \\
\hline $1,3,13$ (Zone I) & $\mathrm{S} 1$ & $446.179,50$ & 1,80 \\
7,19 (Zone II) & $\mathrm{S} 2$ & $257.369,40$ & 0,99 \\
$6,18,24$ (Zone III) & $\mathrm{S} 3$ & $104.323,20$ & 0,38 \\
$2,4,5,8,9,10,11,12,14,15,16$, & $\mathrm{N}$ & - & - \\
$17,20,21,22,23,25,26$ & & &
\end{tabular}

Unit: $1.000 \mathrm{VND} / \mathrm{ha}$.

Table 6. The economical adaptation levels for pineapple cultivation in the studied area

\begin{tabular}{ccccc}
\hline Economical & \multicolumn{4}{c}{ Adaptation level } \\
\cline { 2 - 5 } criteria & $\mathrm{S} 1$ & $\mathrm{~S} 2$ & $\mathrm{~S} 3$ & $\mathrm{~N}$ \\
\hline Profit & $>339.324,80$ & $169.662,40-339.324,80$ & $84.881,20-169.662,40$ & $<84.881,20$ \\
$\mathrm{~B} / \mathrm{C}$ & $>1,32$ & $0,66-1,32$ & $0,33-0,66$ & $<0,33$ \\
\hline
\end{tabular}

Unit: $1.000 \mathrm{VND} / \mathrm{ha}$.

Table 7. The economical adaptation of land for pineapple

\begin{tabular}{llcc}
\hline \multirow{2}{*}{ Land unit } & \multicolumn{2}{l}{ Pineaple cultivation } & \multirow{2}{*}{ Adaptation level } \\
\cline { 2 - 3 } & $\mathrm{LN}$ & $\mathrm{B} / \mathrm{C}$ & $\mathrm{S} 1$ \\
$1,3,13$ (Zone I) & $\mathrm{S} 1$ & $\mathrm{~S} 1$ & $\mathrm{~S} 2$ \\
7,19 (Zone 2) & $\mathrm{S} 2$ & $\mathrm{~S} 2$ & $\mathrm{~S} 3$ \\
$6,18,24$ (Zone 3) & $\mathrm{S} 3$ & $\mathrm{~S} 3$ & $\mathrm{~S}$ \\
\hline
\end{tabular}

Land units: $2,4,5,8,9,10,11,12,14,15,16,17,20,21,22,23,25,26$ were not suitable for Pineaple cultivation.

Table 8. The economical adaptation of land for pineapple

\begin{tabular}{cccc}
\hline Zone & Land unit & Adaptation level & Area (ha) \\
\hline I & $1,3,13$ & S1 & $19.072,85$ \\
II & 7,19 & S2 & $1.210,94$ \\
III & $6,18,24$ & S3 & 944.64 \\
\hline
\end{tabular}

Table 9. The economical and ecological adaptation of land in the studied area

\begin{tabular}{lcccc}
\hline \multirow{2}{*}{ Land unit } & \multicolumn{3}{c}{ Pineapple cultivation } & \multirow{2}{*}{ Adaptation level } \\
\cline { 2 - 4 } & Ecology & Profit & B/C & \\
\hline $1,3,13$ & $\mathrm{~S} 1$ & $\mathrm{~S} 1$ & $\mathrm{~S} 1$ & $\mathrm{~S} 1$ \\
$2,4,5,8,9,10,11,12,14,15,16,17,20,21$, & $\mathrm{N}$ & - & - & $\mathrm{N}$ \\
$22,23,25,26$ & $\mathrm{~S} 3$ & $\mathrm{~S} 3$ & $\mathrm{~S} 3$ & $\mathrm{~S} 3$ \\
$6,18,24$ & $\mathrm{~S} 2$ & $\mathrm{~S} 1$ & $\mathrm{~S} 1$ & $\mathrm{~S} 2$ \\
7,19 & & & & \\
\hline
\end{tabular}

and high interest rates; utilize efficiently the land potential, support the protection, maintenance of land for sustainable development.

Our analysis results on ecological and economical adaptation for pineapple land use; the socioeconomic development orientation of Tan Phuoc; the current status of land use and land characteristics such as soil type, water characteristics, irrigation system, flood control showed that in order to better utilize the ecological conditions for the development of pineapple farming in Tan Phuoc, the regional planning should be grouped into the areas with highly adaptation level (S1, S2) and the areas with low adaptation level (S3), as follow (Figure 4):

$\diamond$ The specialized area for pineapple cultivation: $21,228.42$ ha. This is the area with most of land area were bedded. Furthermore, the trans- 


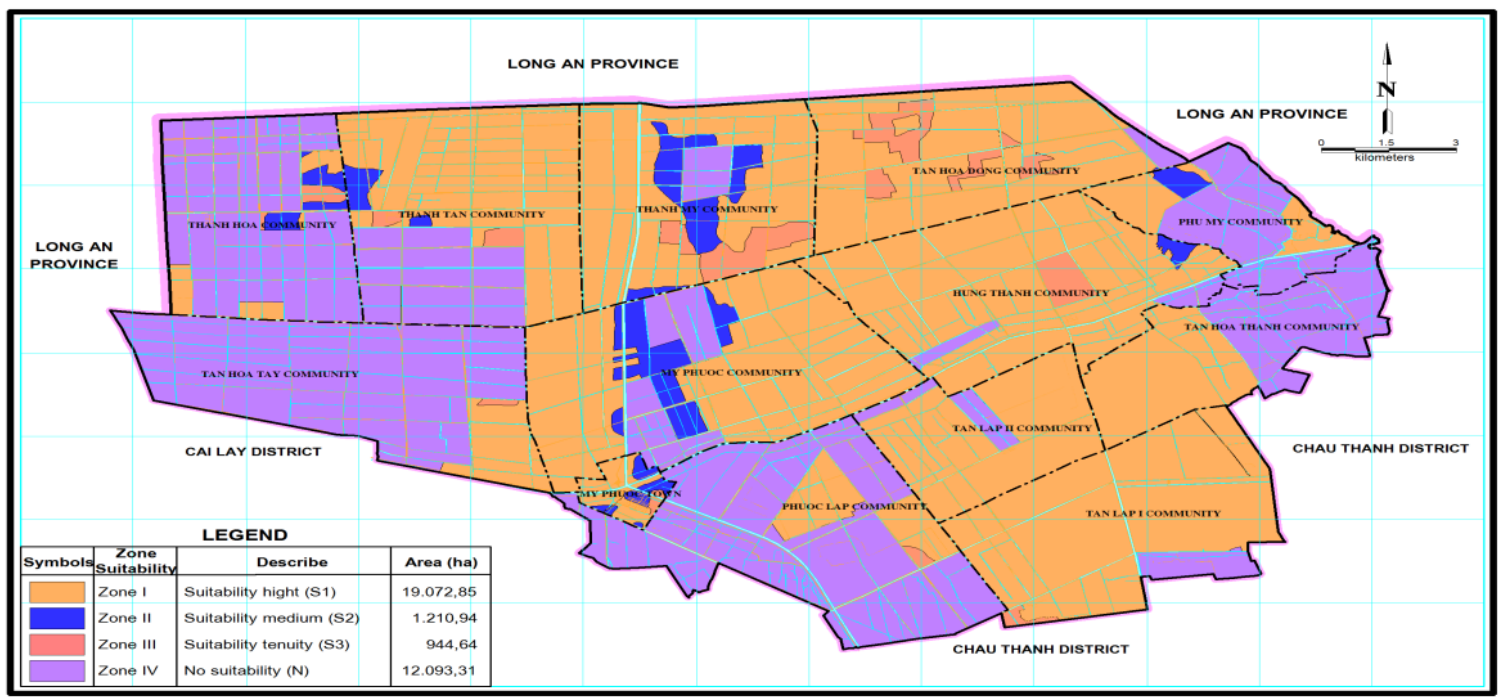

Figure 3. The map of the economical and ecological adaptation for pineapple in Tan Phuoc District, Tien Giang province, Vietnam.

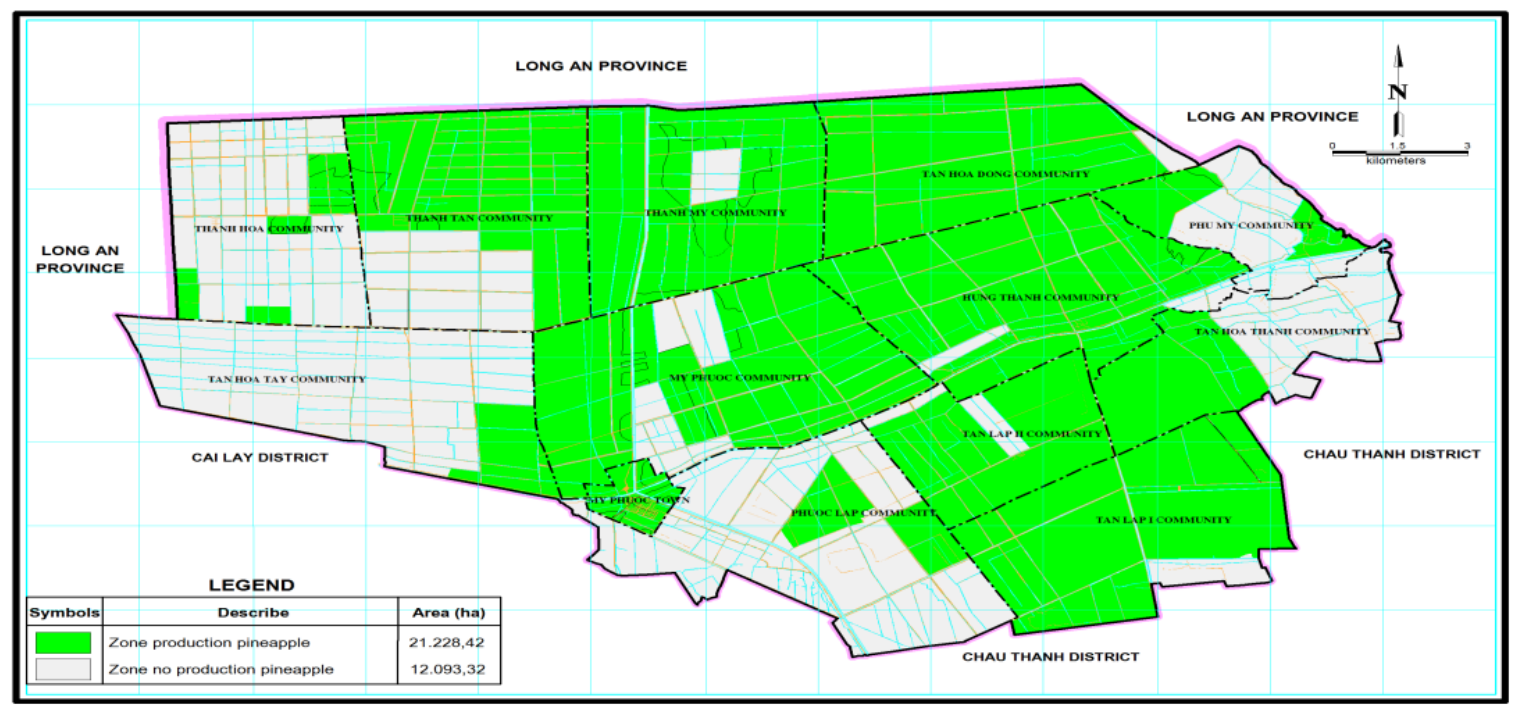

Figure 4. The map of ecological planning for pineapple in Tan Phuoc district, Tien Giang province.

port system, irrigation system and dikes in this area are relatively completed. This is a suitable area for pineapple. This area includes Tan Lap 1, Tan Lap 2, Hung Thanh, My Phuoc, Tan Hoa Đong, Thanh My wards and a part of Thanh Tan ward.

$\diamond$ The unsuitable area for pineapple cultivation: 12,093.32 ha. This is a land area with high level of alum, undeveloped infrastructure, incomplete dike systems. Moreover, this area is frequently flooded and has long flooded periods. This area is not suitable for pineapple cultivation. This area includes Thanh Hoa, Tay Hoa Tay, Phu My, Phuoc Lap and part of Tan Hoa Thanh, Thanh Tan.

\section{Conclusions}

Application of ecological planning for pineapple cultivation (Ananas comosus) helps to uti- 
lize efficiently the ecological and economical conditions for the ideal development of pineapple and therefore the optimal pineapple productivity. This study had mapped and identified the pineapple cultivation area of $21,228.42$ ha (accounting for $63,7 \%$ of the studied area). Our data on the ecological and economical adaptation maps could help to increase pineapple the productivity, protect the environment and support sustainable development in Tan Phuoc district, Tien Giang province.

\section{References}

Almo, F. (1998). Principles and methods in landscape ecology. London, United Kingdom: Chapman \& Hall.

Carol A. J. (1998). Geographic information systems in ecology. Oxford, United Kingdom: John Wiley and Sons Ltd.
DONRE (Department of Natural Resources and Environment of Tien Giang province). (2018). Report on environmental monitoring and natural resource management in Ten Giang 2017. Tien Giang, Vietnam: DONRE Office.

FAO (Food and Agriculture Organization of the United Nations). (1976). A framework for land evaluation. Rome, Italy: FAO.

Huizing H. (1992). Multiple goal analysis for land use planning. In: The proceedings of DLD - ITC workshop on GIS and RS nature resource management (142153). Enschede, The Netherlands.

Nguyen, H. T. N. (2014). A guide to the cultivation of pineapple (Queen). Ha Noi, Vietnam: Agricultural Publishing House. 